\title{
sciendo
}

\section{Exploitation as Theft vs. Exploitation as Underpayment}

\author{
Lamont Rodgers \\ San Jacinto College \\ DOI: $10.2478 /$ disp-2015-0003 \\ BIBLID [0873-626X (2015) 40; pp. 45-59]
}

\begin{abstract}
Marxists claim capitalists unjustly exploit workers, and this exploitation is to show that workers ought to hold more than they do. This paper presents two accounts of exploitation. The Theft Account claims that capitalists steal some of the value to which workers are entitled. The Underpayment Account holds that capitalists are not entitled to pay workers as little as they do, even if the workers are not entitled to the full value they produce. This paper argues that only the Theft Account can explain why workers ought to hold more than they do. The Underpayment Account cannot yield this conclusion. The Theft Account is superior to the Underpayment Account insofar as exploitation is to be an injustice - a wrong that requires the exploited party to hold more.
\end{abstract}

Keywords

Marx, exploitation, theft, underpayment, entitlements.

Marxists hold that capitalists unjustly exploit workers. As a result of this unjust exploitation, we are to be able to infer that workers should have more than capitalists give them. G.A. Cohen argues that the Marxist account of capitalist exploitation of workers rests on the belief that workers are entitled to the surplus product they produce. ${ }^{1}$ Capitalists unjustly seize that surplus product. Call this the "Theft Account" of exploitation. Cohen argues that this commitment is anathema to the egalitarian concerns of Marxists. ${ }^{2}$ If the

${ }^{1}$ Cohen 1995: 211.

${ }^{2}$ The way to think of Cohen's position here is that he is pointing to a tension between the Marxist account of exploitation and Marx's famous dictum "From each according to his abilities, to each according to his needs" (Marx 2008: 27).

Disputatio, Vol. VII, No. 40, May 2015

Received: 03/03/2014 Revised: 17/07/2014 Accepted: 10/10/2014 
worker is entitled to the full value of what he produces, that value (or the goods embodying it) may not be taxed away to achieve egalitarian outcomes. Thus, Cohen claims, the exploitation charge rests on principles at odds with egalitarianism.

Michael Pendlebury, Peter Hudson, and Darrell Mollendorf hold that Marxists can abandon a full-on commitment to the claim that workers are entitled to the value they add to a product while preserving an explanation of why capitalists unjustly exploit their workers. ${ }^{3}$ The crucial move in the Pendlebury piece is to diagnose the fundamental wrong in standard cases of capitalist exploitation, not as the unjust extraction of value to which workers are entitled, but as underpayment. The capitalist is not entitled to pay the worker as little as he does, though the worker may not be entitled to the full value he adds to a product. Call this the "Underpayment Account." The Underpayment Account seeks to preserve the exploitation charge without taking on the problematic claim (for Marxists, anyway) that the worker is entitled to the full value of what he produces.

This paper argues that the Theft Account is superior to the Underpayment Account, insofar as the Marxist wishes to claim that exploitation is sufficient for showing the exploited individual should hold more than he does after the exploitation occurs. The thesis is confined to the role exploitation can play in showing that workers ought to have more than they receive from the capitalist. The Underpayment Account, I argue, renders exploitation neither necessary nor sufficient for the claim that workers ought to have more than they do. All the work related to justice in holdings will be shifted from the exploitative relationship between capitalists and workers to the egalitarian theory of justice Marxists tend to endorse. The Theft Account does not so neuter the role of exploitation in the Marxist analysis of justice in holdings and there is a means of employing the Theft Account without giving up a commitment to modest egalitarianism.

The paper unfolds as follows. Section 1 offers the Theft Account of worker exploitation that G.A. Cohen takes Marxists to accept. Section 2 constructs the Underpayment Account of the Marxist exploitation charge. Section 3 shows that Cohen's understanding of the

${ }^{3}$ Pendlebury et al. 2001. 
exploitation charge offers a superior explanation that is superior to the Underpayment Account of why workers suffer an injustice. The Underpayment Account leaves open the possibility that exploitation is neither necessary nor sufficient for the worker's being due more than they receive.

\section{Exploitation as theft}

In synoptic form, the Marxist charge of worker exploitation is that capitalists steal labor time from their workers. ${ }^{4}$ The standard interpretation of the exploitation charge is that the capitalist unjustly seizes a portion of the value the worker contributes to a product. The worker is thus subjected to an injustice precisely because he does not receive the full value he contributes to a product. G.A. Cohen observed that you can only steal from a person what is properly his. This, Cohen claims, implies that the Marxist exploitation charge takes workers to be the rightful owners of the value they produce.

Cohen aims to show that Marxists are committed to something like the idea that workers are the rightful owners of the surplus product they generate through laboring for capitalists. Marx himself says that capitalists steal labor time from workers and this comes when the capitalists take some of the worker's surplus product. Surplus product here is the value the worker adds to the production process. Pendlebury et al., who are the subject of the following section, nicely hone in on precisely what surplus product is here. ${ }^{5}$

[T] he value the worker adds to the relevant products or services will be worth more than the worker's wages if the capitalist makes a profit from (the worker's) labor. This holds even if value added is computed by subtracting all relevant direct and attributable costs other than the worker's wages from the value of the output towards which the worker has contributed. And here we mean to include the cost of fuel, input materials and services, rent, and the relevant attributable costs of management, accounting, and the amortization and repair of plant and equipment and so on. The only thing we wish to exclude is the surplus

${ }^{4}$ Marx 2003: 307, 458, and 701.

${ }^{5}$ In the text, I refer to the worker's being entitled to the value of what he produces. I should be understood to refer to 'surplus product' when I say that. 
which goes into the capitalists' overall profits, which is not in the ordinary sense a cost. (Pendlebury et al. 2001: 211)

However we spell out this surplus, Marxists hold that capitalists unjustly seize it from workers. And Cohen observes that once one accepts this claim, it is all downhill to the belief that individuals are the rightful owners of their own labor power.

[Y]ou can only steal from someone that which properly belongs to him. The Marxist critique of capitalist injustice therefore implies that the worker is the proper owner of his own labour time... But he could only have that right without having the right to decide what to do with his own capacity to labor, his labor power. (Cohen 1995: 146-147)

Cohen holds that there must be a reason why individuals are the rightful owners of their surplus product. He takes it that the most natural explanation for why the worker who generates surplus product is the person entitled to that surplus is that the worker also owns his own labor time. If one labors, the time one spends laboring cannot be seized. Given Marxism's commitment to (something like) the labor theory of value, ${ }^{6}$ Cohen holds that workers generate titles to some of the value of their labor. Individuals can only own their own labor time, Cohen holds, if they also own their own labor power. For Cohen, labor power simply refers to one's capacity to employ one's body, talents and capacities. Barring the performance of an injustice, individuals cannot be forced to use their labor power for others.

The exploitation charge is a vital portion of the Marxist critique of capitalism. Marxists have long employed the exploitation charge to underpin their judgment that workers should hold more than they do after they suffer exploitation at the hands of capitalists. This claim is, I take it, uncontroversial. Still, to provide some evidence to those who require it, consider that Marx and Engels famously ended The Communist Manifesto by called for workingmen of all countries to unite. ${ }^{7}$ Similarly, Marx and Engels each accused capitalists of stealing from workers. Engels, in a letter to Marx, claimed that he would

\footnotetext{
${ }^{6}$ Almost no one defends the labor theory of value in its original form nowadays, of course.

${ }^{7}$ Marx and Engels 1987: 57.
} 
charge the English bourgeois with robbery, among other things. ${ }^{8}$ The Theft Account, Cohen claims, explains why Marxists say capitalists steal from workers.

As I mentioned above, Cohen goes on to argue that the Theft Account of exploitation is at odds with the egalitarian designs of Marxists. If workers are entitled to the value they contribute to a product, that value may not be taxed away to achieve egalitarian goals. Given this, Marxists require an alternative means of sustaining the exploitation charge - at least to the extent they wish to retain their egalitarian commitments. Accordingly, Pendlebury et al. seek to offer such an account. Section 2 sketches this attempt.

\section{Exploitation as underpayment}

Pendlebury et al. hold that Marxists can abandon a full-on commitment to the claim that workers are entitled to the surplus value they produce. Marxists can drop this commitment while preserving an explanation of why capitalists unjustly exploit their workers. The crucial move in the Pendlebury piece is to diagnose the fundamental wrong in standard cases of capitalist exploitation, not as the unjust extraction of the fruits of the workers' labor, but as underpayment. In particular, the capitalist is not entitled to pay the worker as little as he does. Pendlebury et al. offer the following rival account of the injustice of capitalist exploitation.

In the standard case, the capitalist, because of the power he enjoys by owning means of production, is able to appropriate the product of the worker's labour without having to pay the worker, in exchange, the full value of that product, and the worker must accept this in order to survive. This is unjust exploitation because the capitalist is not morally entitled to pay the worker less than the full value of his labour. (Pendlebury et al. 2001: 209)

As Pendlebury et al. observe "it is absolutely crucial to the account that the capitalist has no moral entitlement to pay the worker

\footnotetext{
${ }^{8}$ Marx and Engels 1953: 28. It is a fascinating complication to the argument I am making that Engels backed away from such strong language in the actual "To the Working Classes of Great Britain.” The language Engels uses is much weaker; and the charges of robbery and murder do not appear.
} 
less than the full value of his labour" (Pendlebury et al. 2001: 210). They add that one might take the capitalist's lack of a right to pay the worker as little as he does "to be inseparable from the worker's right to receive that value from the capitalist" (Pendlebury et al. 2001: 210). The capitalist has no entitlement to pay the workers less than the full value of their labor because "of the absence of factors which could give the capitalist the appropriate moral entitlement" (Pendlebury et al. 2001: 210). Specifically, because the worker has no real choice in whether he will sell his labor or starve, the capitalist cannot offer the worker less than the full value of his labor. The standard cases of capitalist exploitation are unjust precisely because the capitalist is not entitled to pay as little as he does, even if the workers agree to it. The agreement is forced and thus not really an agreement.

It is crucial to see that the Underpayment Account does not aim to diagnose a form of treatment that is always wrong. It is not always wrong to underpay someone. Instead, it is always wrong to underpay someone when the person is forced to choose between working for less than the amount he contributes to a product and starving to death. Pendlebury et al. are forthright about their lack of an account of how entitlements are generated. ${ }^{9}$ But entitlements to objects or pay are irrelevant to the version of the exploitation charge they run. The Underpayment Account does not say the worker is entitled to full payment. Pendlebury et al. hold that a capitalist's entitlement to his holdings does not undermine the Underpayment Account. What is more, the workers do not need to be entitled to the money the capitalist fails to give them.

[I]f a particular capitalist has a moral entitlement to his capital, there are still significant inequalities between his resources and those of his workers, whose survival (we may assume) depends on their being employed by capitalists. Thus, their agreeing to work for him is not an act of free choice, and it therefore does not give him a moral entitlement to pay them less than the full value of their labour. (Pendlebury et al. 2001: 210)

The Underpayment Account seeks to do away with the claim that the worker is entitled to the full value of the product he produces. The question is whether the Underpayment Account preserves the

${ }^{9}$ Pendlebury et al. 2001: 210. 
worker's claim to rectification against the capitalist. In the following section, I show that it does not.

\section{Exploitation of the worker}

At least implicit in the writings of Marxists, not to mention Marx himself, is the message that the worker should have more, as a matter of justice in holdings, than what the capitalists give them. ${ }^{10}$ But the Underpayment Account does not, in itself, provide a reason to believe workers should have more than the capitalists give them. In fact, the Underpayment Account says nothing at all about whether the workers should have anything. The Underpayment Account holds that workers are wronged, but it loses the vital claim that the workers should have more than they receive.

To clarify this last remark, notice that 'injustice' can be used broadly to refer to any sort of wrong, or it can be used narrowly to mean 'denied what one is entitled to as a matter of justice in holdings'. ${ }^{11}$ Not all wrongs require the transfer of a holding from one individual to another. If Jones refuses to buy flowers from Smith because of Smith's race, Jones treats Smith unjustly. Suppose Jones purchases flowers from Ford. Smith is not entitled to the price he is asking for the flowers. He cannot demand money from Jones or Ford. Call such wrongs 'basic wrongs'. However, if Jones takes Smith's flowers and refuses to pay for them, Smith should have more than he does. Call these wrongs 'injustices'. Cohen observes that the Marxist exploitation charge means to point to an injustice workers suffer. The workers are entitled to their surplus value; and that is why it is unjust for the capitalist to seize that value. Thus, workers are due rectificatory payment from capitalists. But one must be struck by the fact that the underpayment account leaves it an open question whether rectificatory payment is due.

The Underpayment Account aims to make it possible that others

\footnotetext{
${ }^{10}$ I leave aside here the possibility that Marx himself did not find exploitation of the worker unjust. Allen Wood argues that Marx did not in Wood 1981. Cohen challenges this claim in Cohen 1983.

${ }^{11}$ The distinction I draw here is sufficient for present purposes. It is certainly not exhaustive.
} 
are entitled to some of the surplus value the worker generates. This aim introduces a vital shift in the Marxist position. As Cohen lays out the exploitation charge, exploitation is sufficient for showing that workers should have more than they do. The worker is entitled to the surplus value he takes and it is unjust to take it from him via exploitation. However, given that others may be entitled to some of the pay the worker receives, the Underpayment Account cannot treat exploitation as sufficient for that conclusion. The Underpayment Account makes it possible that at least some cases of worker exploitation are injustices done not to, but through, workers. To illustrate, imagine that a worker is entitled only to $.6 \mathrm{~V}$, where $\mathrm{V}$ is the value the worker contributes to a product. Suppose the worker is entitled to $.6 \mathrm{~V}$ precisely because there are many infirm individuals in the worker's society. Suppose a capitalist exploits this worker and pays just .6V. Now, if it turns out that others are entitled to .4V, say, to achieve egalitarian goals, the worker has no complaint of injustice against the capitalist. More guardedly, the worker is entitled to nothing more than he receives. Others suffer an injustice at the hands of the capitalist, of course, since ex hypothesi they are entitled to the remaining $.4 \mathrm{~V}$ in order to achieve egalitarian goals. It seems that the question of whether the worker suffers an injustice is not to depend on background conditions like how many infirm people are in the society. But the Underpayment Account makes this a crucial question. So being exploited on the grounds diagnosed by the Underpayment Account is insufficient for generating a claim of rectification against the exploiter.

The previous paragraph also shows that being exploited is also unnecessary for being due more than one is paid. Both the infirm and the worker's children have a claim of injustice against the capitalist, yet they were not exploited. Pendlebury et al. acknowledge that exploitation is not a necessary condition for being due rectification. They hold that "exploitation is not the only possible evil a Marxist should admit" (Pendlebury et al. 2001: 209). And I gather they mean to refer to injustices rather than basic wrongs, for otherwise the claim is a mere banality. Obviously there are wrongs other than exploitation.

Now, Pendlebury et al. have available four lines of response to the primary problem I have diagnosed, viz. that on their model, 
suffering exploitation is insufficient for being due rectification. First, they could hold that it is not outrageous to believe that most cases of capitalist exploitation are in fact cases in which workers should have more than they receive. ${ }^{12}$ Even if that belief is not outrageous, two points are worth making in response. The first is that it is an open question whether workers should receive more payment, whether the belief in question is outrageous or not. On Cohen's rendering, it is not an open question. Notice also that within the Marxist tradition, the motivation for having workers become familiar with Marx was to have the workers see that they were entitled to more than they received, not to have them see that someone other than the capitalist is entitled to the money the capitalist keeps (provided the capitalist is not infirm). ${ }^{13}$

The second point is that, as Pendlebury et al. note, their treatment severely limits the scope of the exploitation charge. As capitalists seek cheap labor through outsourcing, the question of whether workers suffer an injustice ends up, on the underpayment model, depending heavily on the wealth of the capitalist and the wealth of other members of the workers' society. So the appeal to standard cases of exploitation loses its force if it aims to apply the Marxist critique to novel instances of exploitation. The appeal to standard cases seems to have us imagine a fixed society in which there are rich capitalists and lots of exploited workers. But as capitalists with varying degrees of capital enter new markets - markets where there may be no exploited workers - the Underpayment Account of exploitation will be insufficient to yield the judgment that the workers are very likely entitled to more than they receive. More guardedly, if the point of the exploitation charge is to pave the way for egalitarianism, then there are good reasons to believe exploited workers in third world countries, for example, are not entitled to the full surplus value they generate.

The second line of response available to Pendlebury et al. is that they are careful in their rendering of the exploitation charge to stay

\footnotetext{
${ }^{12}$ In a similar vein, Pendlebury et al. claim that it is not outrageous to hold believe that in standard cases, capitalists pay workers less than the full value of his labor. See Pendlebury et al. 2001:211.

${ }^{13}$ Marx and Engels 1953: 556.
} 
away from entitlements workers have. Instead, they locate the wrong in the capitalist's lacking an entitlement to pay workers as little as he does. ${ }^{14}$ What remains unanswered is the question of whether the capitalist's lacking a title to pay the worker what he does means that the worker should receive more. The natural answer for the Marxist is to say that the worker should, but one must notice that the Underpayment Account does not offer this natural answer.

The Underpayment Account holds that workers have a right to the surplus value they produce, but explicitly leaves it an open question whether and why the workers should receive that surplus value. ${ }^{15}$ One might wonder why workers have this right, given that they may lack titles to more than they hold. The fundamental point here is that the underpayment rendering of the exploitation charge does not by itself yield the judgment that workers should have more than they receive from the capitalist.

Insofar as Pendlebury et al. might seek to explain why workers have a right to the full surplus value they produce, even if others are entitled to it, notice that Pendlebury et al. cannot appeal to the workers' having transferred their titles to others. They cannot hold that the workers have transferred these titles and would thus be made guilty of an injustice against others by not receiving full payment from capitalists. Pendlebury et al. hold that the Underpayment Account leaves open that the worker's children and family might be entitled to some of their holdings. But that is insufficient to distinguish the Underpayment Account from Cohen's model. ${ }^{16}$ For almost no one denies that people can transfer titles to a particular quantity of payment even if they have not yet received that payment. A loan is a way of transferring titles to future earnings, for example. All that

${ }^{14}$ Pendlebury et al. 2001: 210.

${ }^{15}$ Pendlebury et al. 2001: 209.

${ }^{16}$ Pendlebury et al. hold that the account Cohen offers is incompatible with the claim that the worker's family or children are entitled to some of the worker's pay. It is unclear why they believe this. Having children, many who believe individuals are entitled to the fruits of their labor hold, is simply a way of making those children entitled to a portion of one's earnings. See John Locke 2009: sections 83 to 89. Of course, some have denied this. Cf. Rothbard 1998: 100. But why the latter is taken as the view is unclear. 
matters is that the individual is entitled to the payment in the first place. The Underpayment Account must leave open that others are entitled to some of the payment, irrespective of whether the worker has transferred titles to those people. But then it becomes a mystery why the worker must have the money pass through his hands as a matter of right.

It is here that a further problem with the Underpayment Account is clear. The Underpayment Account seeks to do without a theory of how titles are generated. Pendlebury et al. confess to having no theory of how entitlements are generated and provide the reader with a lecture to the effect that they are under no special obligation to provide one. However, the view that workers generate titles to their holdings via laboring has long been a centerpiece in Marxist theorizing. Pendlebury et al. purge this centerpiece from Marxist theory and fail to replace it with anything. It is thus unclear whether workers are entitled, even in the most standard cases in which they suffer exploitation, to more than they receive. Such is not the case with the model Cohen provides.

Here is perhaps the most powerful line of response available to Pendlebury et al. In fact, this response is suggested by Pendlebury et al. ${ }^{17}$ The idea is that in Marx's writings, workers are only entitled to the full value they produce after serious redistribution has occurred to achieve egalitarian goals. ${ }^{18}$ After all, Marx's mantra is "From each according to his abilities, to each accord to his need." ${ }^{\prime 19}$ A passage given this pride of place in Marx's writings cannot be ignored.

If this is right, the Theft Account leaves it an open question whether the worker is entitled to the full value he produces. It is in this regard no better off than the Underpayment Account. What is more, the Underpayment Account holds that in standard cases of capitalist exploitation, workers are underpaid. This is the injustice, because in these standard cases, sufficient redistribution to achieve egalitarian goals has not occurred. The Theft Account cannot market itself as an account of exploitation in these standard cases, because

\footnotetext{
${ }^{17}$ Pendlebury et al. 2001: 212.

${ }^{18}$ See Pendlebury et al. 2001: 210-212.

${ }^{19}$ See note 2 above.
} 
we rarely achieve the appropriation conditions for the workers to have entitlements to the full value of his own labor.

This line of response is of only limited success. Grant this reading of the Theft Account. It is still the case that the exploited worker, who is entitled to the full value he produces, provided egalitarian goals are achieved, who should have more than the capitalist gives him. The Theft Account gets us to that conclusion, but the Underpayment Account does not. In the Underpayment Account, we cannot move from the claim that the worker is underpaid to the conclusion that the worker should hold more - even if extensive redistribution has occurred to achieve egalitarian goals. If the worker has such a claim, it will be established by considerations other than that he was underpaid. So while the Underpayment Account might diagnose a wrong in the standard cases of capitalist exploitation, it does not pick out a wrong that shows the exploited ought to hold more than they do.

One final concern worth addressing is the following. One might object that the Theft Account marks too great a departure from the standard Marxist view of the capitalist-worker relationship. ${ }^{20}$ Speaking of rectification suggests that justice is possible under capitalism. After all, if the capitalist offers rectification, their relationship with workers is just. However, Marx and many of his followers have believed that capitalism cannot be just. Thus, the Theft Account is at odds with the traditional view of capitalism.

I believe there are serious questions about whether Marx's stated objections to capitalism justify the judgment that the capitalistworker relation cannot be just. ${ }^{21}$ The locus of these serious questions is the role exploitation is to play in justifying the judgment that capitalism cannot be just. It is common for Marxists to argue that capitalists exploit workers and this exploitation is what makes capitalism unjust. This is the standard rationale for deeming capitalism to be unjust.

If the Theft Account is to be suspect precisely because it suggests capitalism can be just, the Underpayment Account should be equally

${ }^{20}$ I thank an anonymous reviewer for raising this concern.

${ }^{21}$ For explorations of this issue, see Roemer 1985 and section 5 of Mack 2002. 
suspect. The shortcoming of the Underpayment Account is that it either suggests capitalism can be just or provides no reason whatsoever to believe capitalism cannot be just. Let me explain.

Suppose a Marxist were to resist the fundamental thesis of this paper. Suppose that Marxist takes exploitation as underpayment to be sufficient for showing that capitalism cannot be just, then that Marxist has subjected himself to the same objection raised against the Theft Account. If capitalists do not underpay their workers, capitalism can be just. There is nothing about capitalism that in principle precludes capitalists from paying workers for the full value of what they produce. Thus, if the Theft Account is flawed for suggesting capitalism can be just, so is the Underpayment Account.

Of course, I have argued that the Underpayment Account actually does nothing to show that exploited workers ought to hold more than they do. Because of this, the Underpayment Account fails to show that the capitalist-worker relationship cannot be just. As I showed above, underpayment is neither necessary nor sufficient to generate a claim on the worker's part against the capitalist. Thus, if capitalism cannot be just, it is not because of exploitation as underpayment. Marxists require a different explanation of why the capitalist-worker relationship cannot be just. Of course, I think there is an explanation to be had for Marxists: capitalism is incompatible with egalitarianism. This has been the fundamental thesis this article has urged: the Underpayment Account eliminates exploitation from playing any role in showing that workers are due more than they have.

The previous paragraphs do not vindicate the Theft Account of the charge in question, viz. that it suggests the capitalist-worker relation can be just. If a Marxist were interested in holding both that capitalism cannot be just and that exploitation generates a claim on the part of workers, the following move is available. A proponent of the Theft Account could hold that workers are entitled to their surplus only after redistribution has occurred to achieve egalitarian outcomes. I noted the availability of this move above. So the Theft Account could function as a claim-generating wrong only after egalitarian goals are met. As I also showed above, the Underpayment Account can never play such a role. Theft Account is superior to the Underpayment Account even if the conditions under which individuals are entitled to the full value of what they produce are severely limited. 


\title{
Conclusion
}

Insofar as Marxism aims to offer an account of why workers suffer an injustice - a wrong that shows the exploited individual should hold more than he does after being exploited - the Underpayment Account, at least by itself, will not do. The reason for this is clear: the workers need to be entitled to something in order for the capitalists to be required, as a matter of rectificatory justice, to deliver it to them. Insofar as Marxists accuse capitalists of an injustice, Cohen is right to hold that Marxists have long implied that workers are entitled to the value they generate. The underpayment model commits itself to no such claim. The upshot, of course, is not that the underpayment model cannot be part of a Marxist theory. Instead, the upshot is that to the extent that Marxists wish to use the exploitation charge to show that workers are entitled to more than they receive, the explanation must come from reasons other than that they are exploited. Cohen's model is superior in this regard. ${ }^{22}$

\author{
Lamont Rodgers \\ Department of Philosophy \\ San Jacinto College - North Campus \\ 5800 Uvalde \\ Office N7.233 \\ Houston, TX 77049 \\ lamont.rodgers@sjcd.edu
}

\section{References}

Cohen, G.A. 1983. Review of Allen Wood, Karl Marx. Mind 92: 440-445.

Cohen, G.A 1995. Self-Ownership, Freedom, and Equality. Cambridge: Cambridge University Press.

Lenin, Vladimir. 1953. Lenin Collected Works. Moscow: Progress Publishers.

Locke, John. 2009. First Treatise of Civil Government in Two Treatises on Government. Manchester, England: Industrial Systems Research.

Mack, Eric. June 2002. Self-Ownership, Marxism, and Egalitarianism Part II: Challenges to the Self-Ownership Thesis. Politics, Philosophy, and Economics 1(2): 237-276.

${ }^{22}$ I am grateful to Travis Rodgers for providing helpful commentary on an earlier version of this paper. 
Marx, Karl and Engels, Frederick. 1953. Marx Engels Selected Correspondence. Moscow: Foreign Language Publishing House.

Marx, Karl and Engels, Frederick. 1987. The Communist Manifesto. Georgia: Pathfinder Press.

Marx, Karl. 1993. The Grundisse. New York: Penguin Books.

Marx, Karl. 2008. Critique of the Gotha Program. Rockville, MD: Wildside Press. Pendlebury, Michael; Hudson, Peter, and Mollendorf, Darrell. Fall, 2001.

Capitalist Exploitation, Self-ownership and Equality. The Philosophical Forum XXXII (3): 207-220.

Roemer, John. 1985. Should Marxists be Interested in Exploitation? Philosophy and Public Affairs 14(1): 30-65.

Rothbard, Murray. 1998. The Ethics of Liberty. New York: New York University Press.

Wood, Allen. 1981. Karl Marx. New York: Routledge. 